\title{
Purification and Properties of erythro- $\beta-\mathrm{Hydroxyaspartate}$ Dehydratase from Micrococcus denitrificans
}

\author{
By R. G. GIBBS AND J. G. MORRIS \\ Department of Biochemistry, University of Leicester
}

(Received 5 April 1965)

\begin{abstract}
1. The novel enzyme, erythro- $\beta$-hydroxyaspartate dehydratase, a key enzyme of the $\beta$-hydroxyaspartate pathway (Kornberg \& Morris, 1963, 1965), has been purified 30-fold from extracts of glycollate-grown Micrococcus denitrificans. The purified preparation was devoid of erythro- $\beta$-hydroxyaspartate-aldolase activity, and free from enzymes that act on oxaloacetate. 2. Properties of the purified dehydratase were studied by direct assay of the enzymic formation of oxaloacetate and ammonia from added erythro- $\beta$-hydroxyaspartate. 3. The enzyme was highly substrate-specific, utilizing only the L-isomer of erythro- $\beta$-hydroxyaspartate $\left(K_{m}, 0.43 \mathrm{~mm}\right.$, and $V_{\max .}, 99 \mu$ moles of oxaloacetate formed $/ \mathrm{min} . / \mathrm{mg}$. of protein at pH 9.15 and $30^{\circ}$ ). Of many compounds tested, only maleate was a competitive inhibitor $\left(K_{i}, 32 \mathrm{~mm}\right.$ at $\left.\mathrm{pH} 7 \cdot 6\right)$. 4. The optimum $\mathrm{pH}$ for activity was about $9 \cdot 5$. The $K_{m}$ varied with $\mathrm{pH}$, showing a marked optimum at $\mathrm{pH} 7 \cdot 8$. The $V_{\max }$ also varied with $\mathrm{pH}$ in a manner suggesting the presence in the enzyme-substrate complex of a dissociable group of $\mathrm{p} K_{a}^{\prime}$ about 8.5. 5. Carbonyl reagents were inhibitory, but of three thiol reagents tested only $p$-chloromercuribenzoate was inhibitory. 6. A partially resolved preparation of the enzyme was activated fourfold by the addition of pyridoxal phosphate and thereby restored to half activity. 7. EDTA (0.1 mM) was almost completely inhibitory, activity being restored by bivalent cations $\left(\mathrm{Mg}^{2+}, \mathrm{Ca}^{2+}\right.$ and $\left.\mathrm{Mn}^{2+}\right)$; no activation by univalent cations was observed. 8. The findings are discussed in the light of reported properties of related hydroxyamino acid dehydratases.
\end{abstract}

Micrococcus denitrificans, during growth on media in which the sole source of carbon is glycollate or some other direct precursor of glyoxylate, synthesizes the enzymes of the $\beta$-hydroxyaspartate pathway (Kornberg \& Morris, 1963, 1965). Among these is erythro- $\beta$-hydroxyaspartate dehydratase [i.e. erythro-3-hydroxyaspartate hydro-lyase (deaminating)], which catalyses the formation of oxaloacetate and ammonia from erythro- $\beta$-hydroxyaspartate:<smiles>NC(C(=O)O)C(N)C(=O)O</smiles>

However, with crude extracts of glycollate-grown organisms, it is not feasible to measure the activity of this enzyme directly by the assay of keto acid production from $\beta$-hydroxyaspartate, as such extracts are also rich in erythro- $\beta$-hydroxyaspartate aldolase, which, by catalysing the cleavage of $\beta$ - hydroxyaspartate to glycine and glyoxylate, interferes with this assay (Gibbs \& Morris, 1964a). Instead, dehydratase activity has in the past been assayed by coupling the formation of oxaloacetate with the oxidation of $\mathrm{NADPH}_{2}$ by a malate dehydrogenase (EC 1.1.1.37) also present in these extracts (Kornberg \& Morris, 1965).

The present paper reports the preparation of erythro- $\beta$-hydroxyaspartate dehydratase free from contamination with the aldolase and from enzymes that act on oxaloacetate, and reports some of its properties. A preliminary account of certain of these findings has been published (Gibbs \& Morris, 1964b).

\section{METHODS AND MATERIALS}

Maintenance and growth of the organism. The strain of Micrococcus denitrificans, obtained from Dr June Lascelles, had been originally supplied by Dr W. Verhoeven. It was maintained on slopes of glycollate growth medium solidified with $1 \%$ of Ionagar no. 2 (Oxoid Division of Oxo Ltd., London). Cultures of the organism were grown aerobically at $30^{\circ}$ and stored at $2^{\circ}$; they were subcultured weekly. Organisms from these slopes were used to inoculate 11. batches of glycollate medium as described by Kornberg \& 
Morris (1965). The 1l. cultures in turn served as inocula for 601. cultures grown aerobically at $30^{\circ}$ in an NBS continuous-culture apparatus model C.F.500 (New Brunswick Scientific Co., New Brunswick, N.J., U.S.A.). The organisms were harvested during the exponential phase of growth (at a cell density of $0.6 \mathrm{mg}$. dry wt./ml.) by centrifugation at $15000 \mathrm{~g}$ at $2^{\circ}$ in an MSE High Speed 17 centrifuge with continuous-flow attachment (Measuring and Scientific Equipment Ltd., London).

Preparation of a cell-free extract. Harvested organisms were washed by suspension in tris-HCl buffer, $\mathrm{pH} 8(0.01 \mathrm{M})$, containing $\mathrm{MgCl}_{2}(1 \mathrm{~mm})$, followed by centrifugation at $15000 \mathrm{~g}$ for $15 \mathrm{~min}$. at $2^{\circ}$. The washed organisms were resuspended in the same buffer $(50 \mathrm{mg}$. dry wt./ml.) and passed twice through a chilled French pressure cell (American Instrument Co., Silver Spring, Md., U.S.A.) at $12000 \mathrm{lb}$./in. ${ }^{2}$. The extract was freed from residual whole organisms and cell debris by centrifugation at $24000 \mathrm{~g}$ for $1 \mathrm{hr}$. at $2^{\circ}$.

Assay of erythro- $\beta$-hydroxyaspartate aldolase. The activity of this enzyme was measured by the 'indirect' spectrophotometric method and the 'direct' colorimetric procedure, both as described by Kornberg \& Morris (1965).

Assay of malate dehydrogenase ( $E C$ 1.1.1.37). This enzyme was assayed by the spectrophotometric method described by Kornberg \& Morris (1965).

Assay of erythro- $\beta$-hydroxyaspartate dehydratase. Three methods were used.

(a) By measurement of the rate of oxaloacetate formation.

(i) Spectrophotometric method (assay method A). Oxaloacetate formation from added erythro-DL- $\beta$-hydroxyaspartate was measured by following $\mathrm{NADPH}_{2}$ oxidation at $340 \mathrm{~m} \mu$ in the presence of an excess of $\mathrm{NADPH}_{2}$-linked malate dehydrogenase obtained from succinate-grown $M$. denitrificans (Kornberg \& Morris, 1965). The activity of the dehydratase was assessed throughout the course of its purification by this method.

(ii) Colorimetric method (assay method B). Oxaloacetate formed from added erythro-DL- $\beta$-hydroxyaspartate was assayed directly as its 2,4-dinitrophenylhydrazone by the method of Friedemann \& Haugen (1943). This method could only be used when the enzyme had been freed from contamination with erythro- $\beta$-hydroxyaspartate aldolase and from enzymes that would act on oxaloacetate. The complete system contained (in $1 \mathrm{ml}$. final vol.): $100 \mu$ moles of tris-carbonate buffer, $\mathrm{pH} 9,1 \mu$ mole of $\mathrm{MgCl}_{2}, 0.01 \mu$ mole of pyridoxal phosphate, and enzyme $(0 \cdot 15-4 \cdot 0 \mu \mathrm{g}$. of protein). The same mixture, but with enzyme heated at $100^{\circ}$ for $15 \mathrm{~min}$. before use, was used as the reaction 'blank'. The tubes were incubated at $30^{\circ}$ for $5 \mathrm{~min}$. and the reaction was then started by the addition of $10 \mu$ moles of erythro-DL$\beta$-hydroxyaspartate (previously adjusted to $\mathrm{pH} 9$ ). The reaction was stopped, after $10 \mathrm{~min}$. at $30^{\circ}$, by the addition of $0.33 \mathrm{ml}$. of $0.1 \%(\mathrm{w} / \mathrm{v})$ 2,4-dinitrophenylhydrazine in $2 \mathrm{~N}-\mathrm{HCl}$. After $20 \mathrm{~min}$. at $30^{\circ}, 1.67 \mathrm{ml}$. of $10 \%(\mathrm{w} / \mathrm{v}) \mathrm{NaOH}$ was added, and after a further $10 \mathrm{~min}$. at room temperature the developed colour was measured at $455 \mathrm{~m} \mu$ against the reaction 'blank' with a Unicam SP. 600 spectrophotometer. Assuming $\epsilon_{455 \mathrm{~m} \mu}$ for oxaloacetic 2,4-dinitrophenylhydrazone in this assay to be $1.46 \times 10^{4}$, the specific activity of the enzyme was calculated as $\mu$ moles of oxaloacetate produced/ min./mg. of protein.

(b) By measurement of ammonia formation (assay method C). Incubation of the enzyme with erythro-DL- $\beta$ - hydroxyaspartate was carried out as in assay method B, but now the reaction was stopped by the addition of $\mathrm{HClO}_{4}$ (final concn. 5\%, v/v). Any precipitate of protein was removed by centrifugation at $15000 \mathrm{~g}$ and portions of the supernatant were assayed for their content of ammonia by the spectrophotometric method of Holzer, Cennamo \& Boll (1964).

Determination of protein. Soluble protein was generally measured by the method of Lowry, Rosebrough, Farr \& Randall (1951), a standard curve being prepared with crystalline bovine plasma albumin (Armour Laboratories, Eastbourne, Sussex). For the rapid detection of protein in column eluates, spectrophotometric assay at $260 \mathrm{~m} \mu$ and $280 \mathrm{~m} \mu$ (Warburg \& Christian, 1941) was employed.

Measurement of $\mathrm{pH}$. All $\mathrm{pH}$ measurements were made with a direct-reading $\mathrm{pH}$-meter, EIL model 23A (Electronic Instruments Ltd., Richmond, Surrey). The pH of buffer mixtures used in studies of the $\mathrm{pH}$-dependence of enzyme activity was measured at $30^{\circ}$ at the final concentration of buffer used in the experiment.

Preparation of buffers. Tris-carbonate buffers were prepared by the method described by Davis \& Metzler (1962). Methods for the preparation of all the other buffer mixtures used were as reported by Gomori (1955).

Determination of the $K_{m}$ and $V_{\text {max. }}$ values of the enzyme. The activity of the erythro- $\beta$-hydroxyaspartate dehydratase was measured over a suitable range of substrate concentrations by the direct colorimetric assay of the rate of oxaloacetate formation (assay method B). The activity was determined at $\mathrm{pH}$ values other than 9 , by substituting equivalent concentrations of other buffer mixtures for the tris-carbonate used in the standard procedure. The results were plotted, and the $K_{m}$ and $V_{\max }$ values obtained, by the method of Lineweaver \& Burk (1934). Correction was made for the inactivation of the enzyme during assay at low $\mathrm{pH}$ values by the inclusion of control duplicates whose activity was measured after re-establishment of pH9. Correction was also made for the progressive deterioration of the enzyme during storage.

Spectrophotometric procedures. All spectrophotometric assays were performed at room temperature $\left(18-21^{\circ}\right)$ in silica cuvettes $(1.5 \mathrm{ml}$. vol., $1 \mathrm{~cm}$. light-path) with an Optica model CF-4 recording spectrophotometer.

Materials used. erythro- and threo-DL- $\beta$-Hydroxyaspartic acid were purchased from the California Foundation for Biochemical Research, Los Angeles, Calif., U.S.A. Samples of the L- and D-isomers of erythro- $\beta$-hydroxyaspartic acid were prepared from the racemic mixture by resolution as the strychnine and quinine salts, as described by Greenstein \& Winitz (1961). Allo-DL-DL- $\beta$-hydroxyglutamic acid was purchased from Fluka A.-G. Chemische Fabrik, Buchs SG, Switzerland. erythro- and threo-DL- $\beta$-Hydroxy- $\beta$-methylaspartic acid were generously given by Dr T. Jenkins, University of California, Berkeley, Calif., U.S.A. Protamine sulphate 'ex herring' was purchased from L. Light and Co. Ltd., Colnbrook, Bucks. All other reagents were of the highest purity commercially available.

\section{RESULTS}

Partial purification of erythro- $\beta$-hydroxyaspartate dehydratase. The starting material for this purification was the cell-free extract of glycollategrown $M$. denitrificans prepared as described in the 
Methods and Materials section. Unless otherwise stated, all procedures were carried out at $0-4^{\circ}$.

Step 1: heat treatment. Approx. $100 \mathrm{ml}$. of the

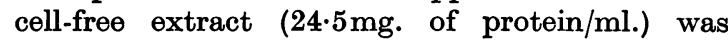
diluted with one-third its volume of $2.0 \mathrm{M}$-trismaleate buffer, $\mathrm{pH} 7 \cdot 0$, and brought to $62^{\circ}$ in a water bath at $70^{\circ}$. It was then maintained at $62^{\circ}$ for exactly $10 \mathrm{~min}$. by constant stirring in a water bath at $62^{\circ}$. After immediate chilling in an ice bath, precipitated protein was removed by centrifuging at $17000 \mathrm{~g}$ for $1 \mathrm{hr}$. The last traces of precipitate were removed by further centrifugation at $75000 \mathrm{~g}$ for $1 \mathrm{hr}$. The resulting supernatant was passed, in two batches, through Sephadex G-25 columns $(50 \mathrm{~cm} . \times 3.5 \mathrm{~cm}$.) that had been equilibrated with $0.01 \mathrm{M}$-tris-hydrochloric acid buffer, $\mathrm{pH} 8$, containing magnesium chloride ( $1 \mathrm{~mm})$. The protein-containing effluents, now at $\mathrm{pH} 8$ and free from maleate, were collected and combined.

Step 2: protamine sulphate treatment. Protamine sulphate solution $(10 \mathrm{mg} . / \mathrm{ml}$.) was added to the product from step 1 in sufficient quantity ( $1 \mathrm{ml} . /$ $100 \mathrm{mg}$. of protein) to precipitate nucleic acid. After standing for $30 \mathrm{~min}$., the suspension was centrifuged at $77000 \mathrm{~g}$ for $1 \mathrm{hr}$. and the supernatant retained.

Step 3: ammonium sulphate precipitation. Ammonium sulphate was added to give $50 \%$ saturation (313g./l.) to the supernatant from step 2, and the $\mathrm{pH}$ immediately readjusted to 8 . The precipitate obtained after standing for $20 \mathrm{~min}$. was removed by centrifugation at $77000 \mathrm{~g}$ for $30 \mathrm{~min}$. To the supernatant was added more ammonium sulphate to give $70 \%$ saturation (137g./1.), the $\mathrm{pH}$ again being readjusted to 8 . After standing for $30 \mathrm{~min}$. the precipitate was collected by centrifugation at $77000 \mathrm{~g}$ for $30 \mathrm{~min}$. and dissolved in about $10 \mathrm{ml}$. of $0.01 \mathrm{M}$-tris-hydrochloric acid buffer, $\mathrm{pH} 8$, containing magnesium chloride ( $1 \mathrm{~mm})$.

Step 4: fractionation by gel filtration. The 50$70 \%$ saturated ammonium sulphate fraction from step 3 was washed through a Sephadex G-200 column $(25 \mathrm{~cm} . \times 2.6 \mathrm{~cm}$.) that had been previously equilibrated with the eluting buffer [0.01 M-trishydrochloric acid buffer, $\mathrm{pH} 8$, containing magnesium chloride ( $1 \mathrm{~mm})$ ]. The effluent was collected in $10 \mathrm{ml}$. fractions, which were assayed for their content of protein and enzyme (see the Methods and Materials section). Fractions 6-8 (Fig. 1) were pooled, and their buffer content was increased to $0.05 \mathrm{M}$-tris-hydrochloric acid buffer, $\mathrm{pH} 8$, containing potassium chloride $(0 \cdot 1 \mathrm{M})$ and magnesium chloride (1 mM), by the addition of the requisite amounts of 1.0M-tris-hydrochloric acid buffer, $\mathrm{pH} 8$, solid potassium chloride and $0 \cdot 1 \mathrm{M}$-magnesium chloride.

Step 5: anion-exchange chromatography. The product from step 4 was applied to a DEAE-

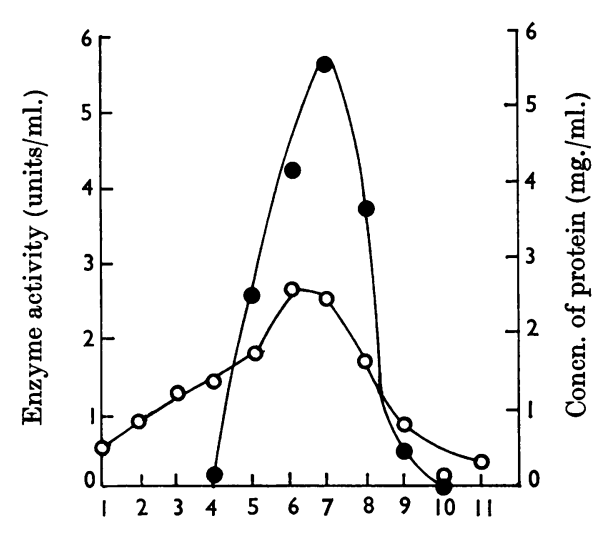

Fraction no.

Fig. 1. Partial purification of dehydratase by filtration through Sephadex G-200. The procedure used is described in the text; the effluent was collected in $10 \mathrm{ml}$. fractions. The protein concentration (O) was measured as described in the Methods and Materials section. erythro- $\beta$-Hydroxyaspartate-dehydratase activity $(\bullet)$ was measured spectrophotometrically in the presence of an excess of $\mathrm{NADPH}_{2}$ linked malate dehydrogenase (assay method A; see the Methods and Materials section). In this assay, 1 unit of enzyme activity is defined as that quantity which leads to the oxidation of $1 \mu$ mole of $\mathrm{NADPH}_{2} / \mathrm{min}$.

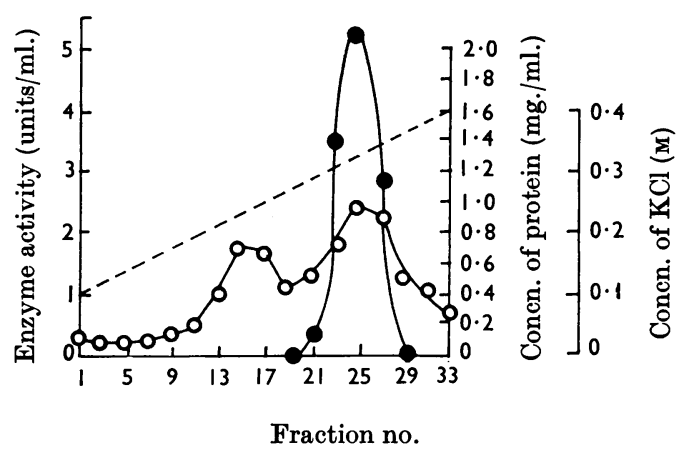

Fig. 2. Elution of dehydratase from DEAE-Sephadex. The procedure used is described in the text; the eluate was collected in $5 \mathrm{ml}$. fractions. The protein concentration (O) and erythro- $\beta$-hydroxyaspartate-dehydratase activity (๑) were measured as described in Fig. 1. The broken line $(--)$ indicates the concentration of the applied $\mathrm{KCl}$ gradient.

Sephadex column $(20 \mathrm{~cm} . \times 1 \cdot 3 \mathrm{~cm}$. $)$ that had previously been equilibrated with $0.05 \mathrm{M}$-tris-hydrochloric acid buffer, $\mathrm{pH} 8$, containing potassium chloride $(0 \cdot 1 \mathrm{M})$ and magnesium chloride (1 $\mathrm{mm})$. The column was washed with this same buffer until no more protein appeared in the effluent, which was 
collected in $5 \mathrm{ml}$. fractions. A linear-gradient device was then attached to the column and a continuously increasing concentration of potassium chloride (from 0.1 to $0.4 \mathrm{M}$ ) was applied in the $0.05 \mathrm{M}$-trishydrochloric acid buffer, pH8, containing magnesium chloride $(1 \mathrm{~mm})$. The eluate was again collected in $5 \mathrm{ml}$. fractions, whose protein and enzyme contents were assayed (Fig. 2). Fractions 23-27 (Fig. 2), which contained the bulk of the dehydratase activity, were pooled, dialysed overnight against three 21 . volumes of $0.01 \mathrm{M}$-trishydrochloric acid buffer, $\mathrm{pH} 8$, containing magnesium chloride (1 $\mathrm{mm}$ ) and pyridoxal phosphate $(10 \mu \mathrm{M})$, and then concentrated by vacuum dialysis to a final volume of $4.5 \mathrm{ml}$.

The complete purification procedure is summarized in Table 1. All erythro- $\beta$-hydroxyaspartatealdolase activity was lost during the step 1 heat treatment, and the final product was devoid of malate-dehydrogenase activity and of other enzymes that act on oxaloacetate. Approximately 30-fold purification of the dehydratase was achieved, yielding a product of high specific activity. Under the conditions of assay method A (i.e. $\mathrm{pH} 8$ and $18^{\circ}$; see the Methods and Materials section) this specific activity equalled $7 \cdot 15 \mu$ moles of $\mathrm{NADPH}_{2}$ oxidized/min./mg. of protein, and in the colorimetric procedure of assay method $\mathrm{B}$ (i.e. pH9.15 and $30^{\circ}$; see the Methods and Materials section) the $V_{\text {max. }}$ was $99 \mu$ moles of oxaloacetate formed $/ \mathrm{min}$./ mg. of protein.

The studies on the properties of the enzyme reported below were all performed with this purified material, whose enzymic activity was assayed throughout (save where otherwise stated) by the colorimetric method for oxaloacetate production (assay method B; see the Methods and Materials section).
Stoicheiometry of action on erythro- $\beta$-hydroxyaspartate. When the enzyme was incubated under the standard assay conditions with erythro-DL- $\beta$ hydroxyaspartate, equal quantities of oxaloacetate and ammonia were produced, and the rate of formation of these products was directly proportional to the amount of enzyme present and to the time of incubation when excess of substrate was supplied. Action of the enzyme on erythro-DL- $\beta$ hydroxyaspartate continued until exactly half of this was consumed, suggesting that only one of the optical isomers was utilized. By using samples of the $L$ - and $D$-isomers of erythro- $\beta$-hydroxyaspartate, it was found that only the L-isomer was a substrate; the D-isomer was not utilized by the enzyme, nor did it inhibit its action on the L-form.

Irreversibility of action. No evidence was obtained for the dehydratase-catalysed synthesis of erythro$\beta$-hydroxyaspartate from oxaloacetate and $\mathrm{NH}_{4}{ }^{+}$ even when these were provided in high concentration. It was concluded that erythro- $\beta$-hydroxyaspartate dehydratase resembles all previously studied hydroxyamino acid dehydratases in catalysing an essentially irreversible deamination reaction (Greenberg, 1961).

Stability. The most highly purified preparations of the dehydratase $(2.5 \mathrm{mg}$. of protein $/ \mathrm{ml}$.) in $0.01 \mathrm{M}$ tris-hydrochloric acid buffer, $\mathrm{pH} 8$, containing magnesium chloride ( $1 \mathrm{~mm}$ ) and pyridoxal phosphate $(10 \mu \mathrm{M})$, gradually decreased in activity when stored, losing one-half of their activity in 10 days at $2^{\circ}$ or in 60 days at $-15^{\circ}$. The effect of $\mathrm{pH}$ on the stability of the enzyme activity was studied by incubating standard amounts of the enzyme for $2 \mathrm{hr}$. at $30^{\circ}$ in buffers of various $\mathrm{pH}$ values. After this treatment, the activity of a portion was assayed by the standard procedure at pH9. The enzyme was evidently most stable in the $\mathrm{pH}$ range

Table 1. Summary of procedure used for purification of erythro- $\beta$-hydroxyaspartate dehydratase from extracts of glycollate-grown M. denitrificans

Enzyme activity was measured spectrophotometrically in the presence of an added excess of $\mathrm{NADPH}_{2}$-linked malate dehydrogenase, by following $\mathrm{NADPH}_{2}$ oxidation at $340 \mathrm{~m} \mu$ (assay method $\mathrm{A}$; see the Methods and Materials section). One unit of enzyme is defined as that quantity which leads to the oxidation of $1 \mu$ mole of $\mathrm{NADPH}_{2} / \mathrm{min}$.

\begin{tabular}{|c|c|c|c|c|c|c|c|}
\hline Step & Material & $\begin{array}{l}\text { Concn. of } \\
\text { protein } \\
\text { (mg./ml.) }\end{array}$ & $\begin{array}{c}\text { Total } \\
\text { volume } \\
\text { (ml.) }\end{array}$ & $\begin{array}{l}\text { Total } \\
\text { protein } \\
\text { (mg.) }\end{array}$ & $\begin{array}{c}\text { Specific } \\
\text { activity } \\
\text { (units/mg. } \\
\text { of protein) }\end{array}$ & $\begin{array}{l}\text { Total } \\
\text { units }\end{array}$ & $\begin{array}{c}\text { Yield } \\
\text { ( } \% \text { of } \\
\text { initial } \\
\text { enzyme } \\
\text { content) }\end{array}$ \\
\hline & Cell extract & $\mathbf{2 4 \cdot 5}$ & 148 & 3625 & $0 \cdot 245$ & 890 & 100 \\
\hline 1 & $\begin{array}{l}\text { Heat-treated extract after Sephadex } \\
\text { G-25 filtration }\end{array}$ & $\mathbf{3 \cdot 5}$ & 210 & 735 & 0.460 & 340 & 38 \\
\hline 2 and 3 & $\begin{array}{l}50-70 \% \text { Satd. }\left(\mathrm{NH}_{4}\right)_{2} \mathrm{SO}_{4} \text { fraction of } \\
\text { protamine sulphate supernatant }\end{array}$ & $13 \cdot 6$ & 11 & $149 \cdot 6$ & $1 \cdot 410$ & 210 & 24 \\
\hline 4 & Sephadex G-200 effluent & $2 \cdot 25$ & 30 & $67 \cdot 5$ & $2 \cdot 020$ & 140 & 15 \\
\hline 5 & DEAE-Sephadex eluate & 0.54 & 25 & $13 \cdot 5$ & $7 \cdot 150$ & 97 & 11 \\
\hline
\end{tabular}




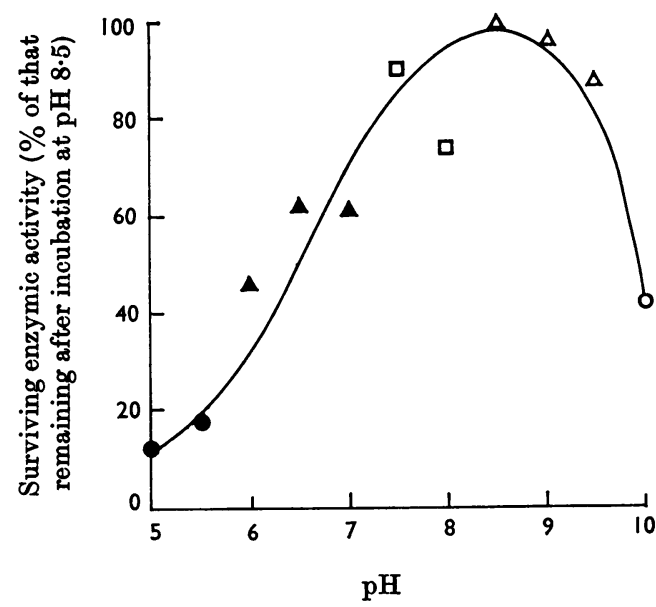

Fig. 3. Effect of pH on the stability of purified erythro- $\beta$ hydroxyaspartate dehydratase. Purified enzyme (about $0.3 \mu \mathrm{g}$. of protein $/ \mathrm{ml}$.) in $0.05 \mathrm{~m}$-buffer (whose $\mathrm{pH}$ was determined at $30^{\circ}$ ) was incubated at $30^{\circ}$ for exactly $2 \mathrm{hr}$. The $\mathrm{pH}$ of a sample was adjusted to 9 with tris-carbonate buffer (final concn. $0.1 \mathrm{M}$ ) and the dehydratase activity assayed by the colorimetric procedure (assay method B; see the Methods and Materials section). Buffers used were: carbonate-bicarbonate $(0)$, tris-carbonate $(\Delta)$, tris- $\mathrm{HCl}$ $(\square)$, phosphate $(\Delta)$ and acetate $(\bullet)$

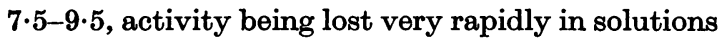
more acid than $\mathrm{pH} 6$ or more alkaline than $\mathrm{pH} 10$ (Fig. 3).

Effect of $\mathrm{pH}$ on activity. Not only the stability but also the activity of erythro- $\beta$-hydroxyaspartate dehydratase was markedly dependent on $\mathrm{pH}$. Under the conditions of the standard assay, but with the tris-carbonate buffer, pH9, replaced by an equivalent concentration of buffers of other $\mathrm{pH}$, the enzymic activity apparently increased with increasing $\mathrm{pH}$ in the range 5-9.5 even when allowance was made for the irreversible inactivation of some of the enzyme at unfavourable $\mathrm{pH}$ values (see the Methods and Materials section). The optimum pH for activity of the dehydratase seemed to be about $\mathrm{pH} \mathrm{9.5} \mathrm{(Fig.} \mathrm{4).} \mathrm{The} \mathrm{effect} \mathrm{of} \mathrm{pH}$ was examined more fully by investigating the effects of $\mathrm{pH}$ on the $K_{m}$ and $V_{\max }$. values of the enzyme (see the Methods and Materials section). The $K_{m}$ was markedly dependent on $\mathrm{pH}$, a graph of $\mathrm{p} K_{m}$ (i.e. $-\log K_{m}$ ) against $\mathrm{pH}$ showing a maximum at $\mathrm{pH} 7 \cdot 8$ (Fig. 5). The $V_{\max \text {. also increased with increasing }}$ pH over the range 5-9, thereafter remaining virtually constant at about $100 \mu$ moles of oxaloacetate formed/min./mg. of protein up to $\mathrm{pH} 10$, which was the most alkaline condition tested (Fig. 6).

Substrate specificity. The enzyme did not catalyse keto acid formation from $\beta$-hydroxy- $\alpha$-amino acids

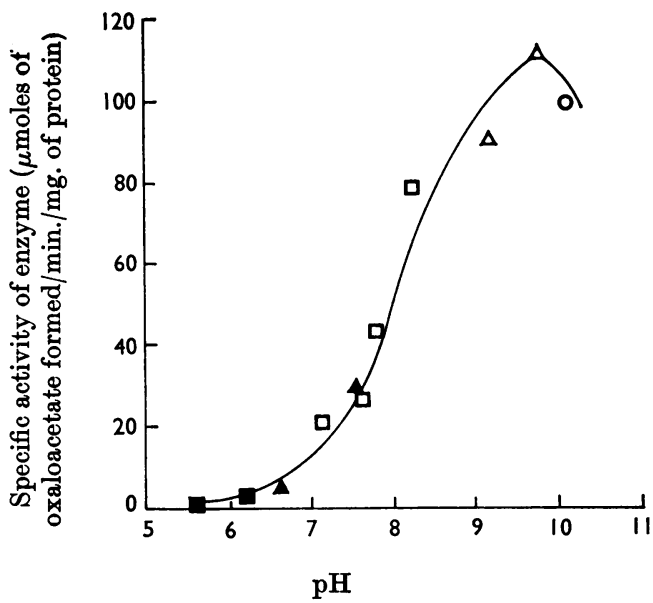

Fig. 4. Effect of $\mathrm{pH}$ on the activity of purified erythro- $\beta$ hydroxyaspartate dehydratase. The experimental procedure followed is described in the text. Buffers used were: carbonate-bicarbonate $(O)$, tris-carbonate $(\Delta)$, tris- $\mathrm{HCl}$ $(\square)$ phosphate $(\Delta)$ and citrate-phosphate $(\square)$.

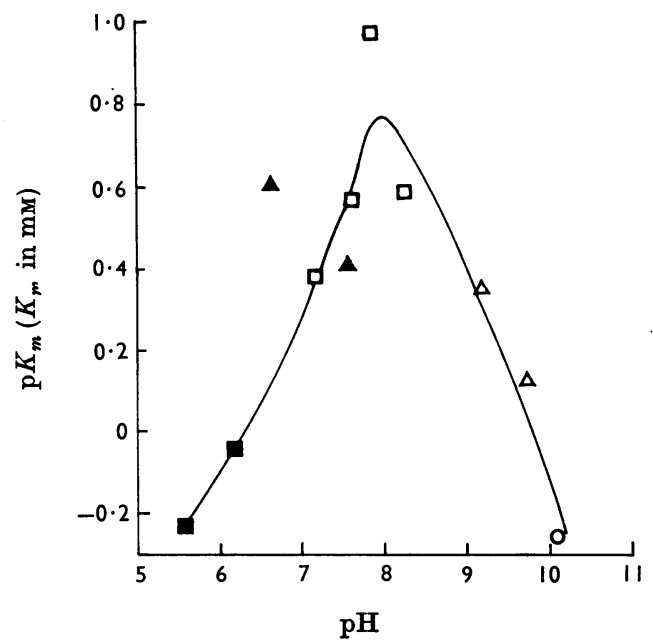

Fig. 5. pH-dependence of $K_{m}$ for the action of purified erythro- $\beta$-hydroxyaspartate dehydratase on erythro-L- $\beta$ hydroxyaspartate. The $K_{m}$ values (mM) were determined as described in the Methods and Materials section, and plotted logarithmically as $\mathrm{p} K_{m}$ (i.e. $-\log K_{m}$ ). The buffers used were as given in Fig. 4.

other than erythro-L- $\beta$-hydroxyaspartate when these were tested at twice the normal substrate concentration under the conditions of assay method $B$ (see the Methods and Materials section). Compounds tested and not utilized included threo-DL- $\beta$ hydroxyaspartate, erythro-and threo-DL- $\beta$-hydroxy- 


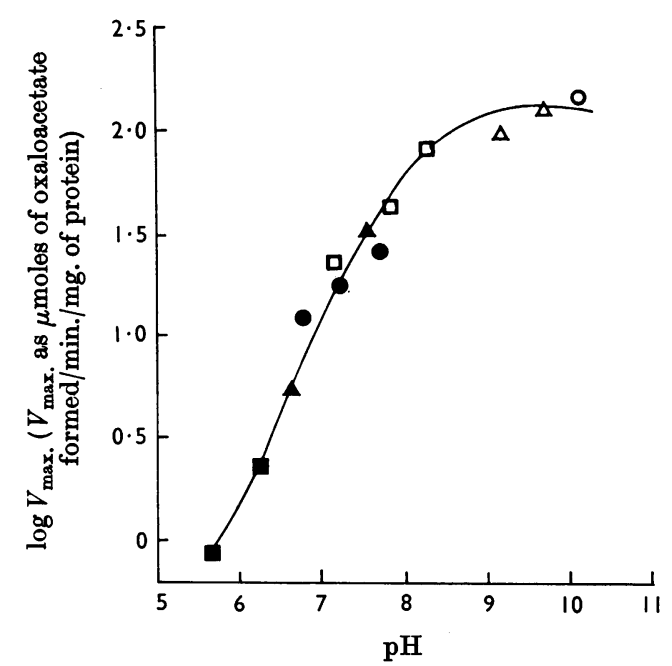

Fig. 6. pH-dependence of $V_{\max }$ of the action of purified erythro- $\beta$-hydroxyaspartate dehydratase on erythro-L- $\beta$ hydroxyaspartate. The $V_{\max }$. values were determined as described in the Methods and Materials section and are plotted logarithmically. The buffers used in the $V_{\max }$. determinations were tris-maleate $(\bullet)$ and those buffer mixtures identified in Fig. 4.

Table 2. Inhibition of erythro- $\beta$-hydroxyaspartate dehydratase by carbonyl reagents

Purified enzyme (about $14 \mu \mathrm{g}$. of protein $/ \mathrm{ml}$.) was preincubated at $\mathrm{pH} 6.5$ for $15 \mathrm{~min}$. at $37^{\circ}$ with the test concentration of carbonyl reagent. After adjustment of the pH to 8 with tris-HCl buffer, erythro-DL- $\beta$-hydroxyaspartate $(10 \mu \mathrm{moles} / \mathrm{ml}$.) was added and the mixture incubated at $30^{\circ}$ for exactly $10 \mathrm{~min}$. Protein was precipitated with $\mathrm{HClO}_{4}$ and removed by centrifugation and the ammonia content of the supernatant measured, all as described in assay method $\mathrm{C}$ (see the Methods and Materials section). The activity of the treated enzyme is expressed as a percentage of the activity of the same enzyme preparation preincubated and assayed as described, but in the absence of added carbonyl reagent.

$\begin{array}{lc}\text { Carbonyl reagent } & \begin{array}{c}\text { Activity of } \\ \text { treated enzyme (\%) }\end{array} \\ \text { Semicarbazide (20 mM) } & 17 \\ \text { Semicarbazide (2 mM) } & 45 \\ \text { Isoniazid (20 mM) } & 58 \\ \text { Isoniazid (2 mM) } & 85 \\ \text { Hydroxylamine (0.10 mM) } & \mathrm{Nil} \\ \text { Hydroxylamine (0.01 } \mathrm{mm}) & 82\end{array}$

$\beta$-methylaspartate, allo-DL-DL- $\beta$-hydroxyglutamate, and the $L$ - and $D$-isomers of serine, threonine and allothreonine. No oxaloacetate was formed when the enzyme was incubated with D- or Laspartate or any isomer of tartrate.
Inhibition by carbonyl reagents. The action of carbonyl reagents was assessed by their effect on the enzymic release of ammonia from erythro- $\beta$ hydroxyaspartate at $\mathrm{pH} 8$ (Table 2). All the compounds tested were inhibitory, hydroxylamine being particularly potent in causing complete inhibition at $0.1 \mathrm{~mm}$.

Inhibition by thiol reagents. These were tested under the conditions of assay method B (see the Methods and Materials section). Of the three compounds used, iodoacetate and $N$-ethylmaleimide were without effect at comparatively high concentration ( $1 \mathrm{~mm})$, but $p$-chloromercuribenzoate was inhibitory. The effectiveness of $p$-chloromercuribenzoate as an inhibitor of dehydratase activity varied from preparation to preparation of the enzyme, a concentration of $0 \cdot 2 \mathrm{~m}$ M causing $25-100 \%$ inactivation. The simultaneous addition of reduced glutathione (3mM) protected the enzyme against inhibition by $0.3 \mathrm{~mm}-p$-chloromercuribenzoate. When the enzyme was preincubated with this concentration of $p$-chloromercuribenzoate, which was then removed as completely as possible by prolonged dialysis, the subsequent addition of reduced glutathione $(3 \mathrm{mM})$ did not restore activity.

Inhibition by substrate analogues. The activity of the dehydratase was measured under standard assay method $B$ conditions in the presence of the substrate analogue $(10 \mathrm{~mm})$, which was added $5 \mathrm{~min}$. before the addition of the erythro-DL- $\beta$-hydroxyaspartate ( $1 \mathrm{~mm}$, i.e. $0.5 \mathrm{~mm}$ of the L-substrate). No inhibition was noted with threo-DL- $\beta$-hydroxyaspartate, erythro- and threo-DL - $\beta$-hydroxy - $\beta$ methylaspartate, allo-DL-DL- $\beta$-hydroxyglutamate, chloromalate, glycine, D-, L- and meso-tartrate, and the $\mathrm{D}$ - and $\mathrm{L}$ - isomers of allothreonine, threonine, aspartate, $\beta$-methylaspartate, serine, alanine and malate, nor was there any evidence of product inhibition by oxaloacetate and $\mathrm{NH}_{4}{ }^{+}$. Indeed, the only substrate analogue found to be inhibitory was maleate. Examination of the kinetics of inhibition of dehydratase activity by a fixed concentration of maleate at various substrate concentrations (by the method of Lineweaver \& Burk, 1934) showed that this inhibition was competitive $\left(K_{i}, 32 \mathrm{~mm}\right.$ at pH 7.6, when $K_{m}$ for erythro-L- $\beta$-hydroxyaspartate was $0.21 \mathrm{mM}$ ).

Requirement for pyridoxal phosphate. Inhibition of dehydratase activity by carbonyl reagents (Table 2) would be explicable if pyridoxal phosphate were present as coenzyme. A quantity of enzyme was dialysed overnight against hydroxylamine $(0.1 \mathrm{~mm})$ in $0.01 \mathrm{M}$-tris-hydrochloric acid buffer, pH 8, containing magnesium chloride (1 mM). Free hydroxylamine was then removed from the inactivated enzyme by prolonged dialysis against several volumes of the same buffer but minus hydroxylamine. The preparation was still without activity, 
and incubation with excess of pyridoxal phosphate $(0 \cdot 1 \mathrm{~mm})$ did not restore activity. 4'-Deoxypyridoxine phosphate $(0.1 \mathrm{mM})$ was not inhibitory, nor did it protect the enzyme against inactivation at low $\mathrm{pH}$ values. However, direct evidence of the involvement of pyridoxal phosphate was obtained with a batch of enzyme that had been eluted from a DEAE-Sephadex column with a high concentration of tris-hydrochloric acid buffer, $\mathrm{pH} 7 \cdot 75(0.5 \mathrm{M})$, containing magnesium chloride ( $1 \mathrm{mM}$ ). The enzyme preparation so obtained was of decreased activity, which was enhanced fourfold (and thereby restored to half the normally observed activity) by the addition of pyridoxal phosphate $(0.01 \mathrm{~mm})$.

Activation by bivalent cations. The addition of magnesium chloride $(1 \mathrm{~mm})$ to a sample of the dehydratase that contained added magnesium chloride at $3 \mu \mathrm{M}$ concentration only slightly enhanced its activity. However, EDTA was a potent inhibitor of the enzyme and almost abolished its activity when added at $0.1 \mathrm{~mm}$ (Table 3). The activity of the EDTA-inhibited enzyme could be fully restored by addition of bivalent cations. Of these, $\mathrm{Mg}^{2+}$ and $\mathrm{Ca}^{2+}$ were approximately equally effective, and $\mathrm{Mn}^{2+}$ was somewhat less efficient (Table 3). No evidence for an additional or alternative univalent cation requirement was obtained.

Other activators. There was no 'product activation' by oxaloacetate or $\mathrm{NH}_{4}{ }^{+}$(each $20 \mathrm{~mm}$ ) when the enzyme was preincubated with these before the addition of erythro-DL- $\beta$-hydroxyaspartate $(10 \mathrm{~mm})$. Similarly, there was no detectable activation of the

Table 3. Inhibition of erythro- $\beta$-hydroxyaspartatedehydratase activity by EDTA and its reversal by bivalent cations

Purified enzyme (about $1 \mu \mathrm{g}$. of protein $/ \mathrm{ml}$.) was preincubated at $30^{\circ}$ for $5 \mathrm{~min}$. with the test concentration of EDTA in the assay method $\mathrm{B}$ mixture, $\mathrm{pH} 9$, minus substrate. It was calculated that approx. $3 \mu \mathrm{M}$-free $\mathrm{Mg}^{2+}$ was introduced into this mixture with the purified enzyme sample. The enzymic activity was measured by assay method B (see the Methods and Materials section) in the presence of the test concentration of the bivalent cation (added as the chloride). Enzyme activities are expressed as a percentage of the activity after similar treatment of the enzyme in the absence of added EDTA when assayed in the presence of added $\mathrm{MgCl}_{2}(1 \mathrm{mM})$. - , Not tested.

\begin{tabular}{|c|c|c|c|c|c|}
\hline \multirow{2}{*}{$\begin{array}{c}\text { Added } \\
\text { bivalent } \\
\text { cation }\end{array}$} & \multirow{2}{*}{$\begin{array}{l}\text { Concn. of } \\
\text { EDTA (mM) }\end{array}$} & \multicolumn{4}{|c|}{ Enzyme activity (\%) } \\
\hline & & $\cdots 0$ & 0.1 & $1 \cdot 0$ & $10 \cdot 0$ \\
\hline & 95 & 12 & 16 & 13 \\
\hline \multicolumn{2}{|c|}{$\mathrm{Mg}^{2+}(1 \cdot 0 \mathrm{~mm})$} & 100 & 100 & 16 & 16 \\
\hline \multicolumn{2}{|c|}{$\mathrm{Mg}^{2+}(10.0 \mathrm{~mm})$} & 100 & 97 & 91 & 85 \\
\hline \multicolumn{2}{|c|}{$\mathrm{Ca}^{2+}(10.0 \mathrm{mM})$} & - & - & 90 & - \\
\hline \multicolumn{2}{|c|}{$\mathrm{Mn}^{2+}(10.0 \mathrm{~mm})$} & - & - & 73 & 一 \\
\hline
\end{tabular}

dehydratase by AMP or ADP (3 mM) or by $\alpha$-oxo acids such as pyruvate and $\alpha$-oxoglutarate ( $1 \mathrm{mM}$ ) when these were tested in assay system $B$ (the formation of $\mathrm{NH}_{4}+$ being followed when the keto acids were tested). Of many other compounds tested, only reduced glutathione enhanced activity of the enzyme in the presence of pyridoxal phosphate and $\mathrm{Mg}^{2+}$. This stimulation of activity by reduced glutathione was not reproducible from one preparation of the enzyme to the next; the activity of the most susceptible (aged) preparation was enhanced $70 \%$ by the addition of excess of reduced glutathione (3mM).

\section{DISCUSSION}

erythro- $\beta$-Hydroxyaspartate dehydratase is remarkable in the specificity of its action on erythro$\mathrm{L}-\beta$-hydroxyaspartate. This is in contrast with the lower specificity of erythro- $\beta$-hydroxyaspartate aldolase, whose ability to act on the $\beta$-methyl derivative of erythro- $\beta$-hydroxyaspartate is the basis of its assay in the presence of an excess of the dehydratase (Gibbs \& Morris, 1964a).

Although by the reported procedure the dehydratase was purified only 30 -fold, the $V_{\text {max. }}$ of the final preparation compared favourably with the $V_{\text {max. }}$ values reported for other hydroxyamino acid dehydratases purified 200-1500-fold from less rich sources, e.g. mammalian liver (Greenberg, 1961; Davis \& Metzler, 1962). Further, the erythro- $\beta$ hydroxyaspartate dehydratase of $M$. denitrificans has proved more amenable to kinetic studies than similar enzymes of microbial origin that were subject to substrate or end-product activation (Bridgeland \& Jones, 1965; Holzer et al. 1964).

The Michaelis constant, $K_{m}$, of the dehydratase, when acting on erythro-L- $\beta$-hydroxyaspartate $(0.43 \mathrm{~mm}$ at $\mathrm{pH} 9 \cdot 15)$, was similar to the $K_{m}$ values of other hydroxyamino acid dehydratases when acting on their best substrates (Greenberg, 1961). The manner in which the $K_{m}$ varied with the $\mathrm{pH}$ resembles the behaviour of $L$-threonine dehydratase (Davis \& Metzler, 1962), which was interpreted as indicating the binding of the substrate in its anionic form to the enzyme, presumably via a pyridoxal phosphate coenzyme. The $\mathrm{pH}$-dependence of $V_{\max }$, on the other hand, contrasts with the $\mathrm{pH}$-independence of $V_{\max }$ of the same L-threonine dehydratase (Davis \& Metzler, 1962), and suggests the existence in the enzyme-substrate complex of a dissociable group of $\mathrm{p} K_{a}^{\prime}$ about 8.5 . The action of maleate as a competitive inhibitor (and thus as a protective agent against denaturation of the enzyme during heat treatment) contrasts with the complete inactivity of any isomer of threonine, and suggests that two ionized carboxylic groups are necessary for the formation of the enzyme-substrate complex. 
The inhibitory effect of carbonyl reagents on other hydroxyamino acid dehydratases had been interpreted as evidence of the participation of pyridoxal phosphate (Greenberg, 1961). Activation of a partially resolved preparation of the erythro- $\beta$ hydroxyaspartate dehydratase by added pyridoxal phosphate would seem to justify this assumption, though more direct spectrophotometric evidence awaits the further purification of the enzyme. The possible requirement for free thiol groups remains in doubt, although supported by the occasional activation achieved by reduced glutathione, and by the inhibition caused by $p$-chloromercuribenzoate, though alkylating thiol reagents were without effect. However, it has been proposed that $p$-chloromercuribenzoate might act, not only as a thiol inhibitor, but also by promoting the dissociation of pyridoxal phosphate from its coenzymic site (Grein \& Pfleiderer, 1958), or by causing disaggregation of protein sub-units (Gerhart, 1964). AMP and ADP, which activated threonine dehydratase obtained from microbial sources (Umbarger \& Brown, 1957; Whiteley \& Hayaishi, 1964), had no effect on erythro- $\beta$-hydroxyaspartate dehydratase, and no overt allosteric activators or inhibitors of this enzyme were discovered. However, since a heattreatment step was included in the purification procedure (to inactivate and possibly remove erythro- $\beta$-hydroxyaspartate aldolase), the preparation might not demonstrate the allosteric properties of the native enzyme, though none was disclosed by spectrophotometric assay of enzymic activity in crude unheated preparations.

The function of the bivalent cation is not known. It is unlikely that these cations act by promoting the tautomerization of the free oxaloacetate product, since $(a)$ the method of assay measured the 'total' amount of oxaloacetate formed, i.e. both enol and keto forms, and (b) comparatively high concentrations of oxaloacetate (containing all tautomers) were not inhibitory. It remains possible that they might either promote the liberation of the product from the active site of the enzyme, or act as activators, even if they did not participate directly in the establishment of the enzymesubstrate complex.

We thank Mrs Janet Tomlinson for skilled technical assistance. R. G. G. was in receipt of a Medical Research Council Training Scholarship, and the work was sponsored in part by the U.S. Air Force Office of Scientific Research O.A.R. under Grant no. AF-EOAR 63-17 monitored by the European Office, Aerospace Research, U.S. Air Force.

\section{REFERENCES}

Bridgeland, E. S. \& Jones, K. M. (1965). Biochem. J. 94, $29 \mathrm{P}$.

Davis, L. \& Metzler, D. E. (1962). J. biol. Chem. $237,1883$.

Friedemann, T. E. \& Haugen, G. E. (1943). J. biol. Chem. $143,415$.

Gerhart, J. C. (1964). Brookhaven Symp. Biol. 17, 222.

Gibbs, R. G. \& Morris, J. G. (1964a). Biochim. biophys. Acta, $85,501$.

Gibbs, R. G. \& Morris, J. G. (1964b). Biochem. J. 92, 54 P. Gomori, G. (1955). In Methods in Enzymology, vol. 1, p. 138. Ed. by Colowick, S. P. \& Kaplan, N. O. New York: Academic Press Inc.

Greenberg, D. M. (1961). In The Enzymes, vol. 5, p. 563. Ed. by Boyer, P. D., Lardy, H. \& Myrbäck, K. New York: Academic Press Inc.

Greenstein, J. P. \& Winitz, M. (1961). Chemistry of the Amino Acids, vol. 3, p. 2417. New York: John Wiley and Sons Inc.

Grein, L. \& Pfleiderer, G. (1958). Biochem. Z. 330, 433.

Holzer, H., Cennamo, C. \& Boll, M. (1964). Biochem. biophys. Res. Commun. 14, 487.

Kornberg, H. L. \& Morris, J. G. (1963). Nature, Lond., $197,456$.

Kornberg, H. L. \& Morris, J. G. (1965). Biochem.J. 95, 577.

Lineweaver, H. \& Burk, D. (1934). J. Amer. chem. Soc. $56,658$.

Lowry, O. H., Rosebrough, N. J., Farr, A. L. \& Randall, R. J. (1951). J. biol. Chem. 193, 265.

Umbarger, H. E. \& Brown, B. (1957). J. Bact. 73, 105.

Warburg, O. \& Christian, W. (1941). Biochem. Z. 310, 384.

Whiteley, H. R. \& Hayaishi, O. (1964). Biochem. biophys. Res. Commun. 14, 143. 